\title{
THE LIBRARY ASSOCIATION CONFERENCE AT BRIGHTON
}

$\mathrm{T}$ HE papers presented at the annual conference of the Library Association at Brighton during September 23-26 ranged over a wide field, but the two of most direct interest to the scientist are those in which Mr. W. L. A. Saunders, deputy-librarian, University of Sheffield, discussed current problems of university libraries, and Mr. C. H. Wright, county technical librarian, Hertfordshire, those of special libraries.

Prof. Raymond Irwin in his presidential address reviewing the work and technique of librarianship, including committee work and the place and value of conferences, insisted that librarianship was all directly and closely connected with books and their proper use. The librarian's first responsibility was to help others to read or to find information. His second responsibility was to read himself : to read intelligently, systematically; widely but not aimlessly; with understanding, with sympathy and with appreciation. No routine should be tolerated which hindered rather than helped the discharge of these responsibilities, and Prof. Irwin urged an honest and unprejudiced review of all routines. Books, he insisted, were never more alive than to-day : there was no substitute for the book and there never would be. Finally, insisting on the importance of the librarian himself and the limitations of administrative and bibliographic techniques, Prof. Irwin said that British librarians and librarianship were to-day being exported to Australia, Africa, the Middle East, Canada, the Caribbean and the United States, but there was grave need to increase the export of British books, particularly scientific and technical books, to many parts of the world besides Pakistan. With these books must go British ideas about books and about librarianship, and he hoped we would continue to send out both British librarians and British-trained librarians.

Mr. Saunders said that the main problem facing universities and university librarians at present arises from the increase in the student population, from 50,000 in 1939 to 90,000 at present, with at least 124,000 expected by 1965. At Sheffield it had risen from 767 in 1939 to about 2,000 in 1952, and early this year a target of 4,500 was set. The increase had already set a severe strain on storage space and seating accommodation in many libraries, and the latter was aggravated by the fact that a relatively small proportion of students lived in halls of residence. Few university libraries held excessively large collections, but several were near the 400,000 and 500,000 marks, and in twenty or thirty years many provincial university libraries were likely to approach a million volumes. Collections of this order could daunt new students, and the problem of providing an adequate introduction for an annual intake of several hundred students was serious. In addition to an introductory tour, Mr. Saunders suggested that all undergraduates should at least be made aware of the bibliographical tools of their own field. The whole question of departmental libraries required objective review, and finally he stressed the importance of providing a reasonable salary scale for non-graduate staff so as to attract those capable of relieving the graduate staff of work which did not require high academic qualifications.

Mr. C. H. Wright, pointing out that the special library in the past was chiefly concerned with the flow of information, whereas the public and university libraries were concerned with the flow of books, said that with the vast expansion of scientific and technical literature, the mechanics of organizing the flow of information had become as important to the special librarian as the degree of subject knowledge, while the increasing demand for scientific, technical and commercial information had made the public librarian more aware of the value of specialized subject knowledge. There was thus a better understanding of what are the common foundations of librarianship. After reviewing the problems of staffing a special library and suggesting that more attention should be given to the question of providing suitable training, Mr. Wright said that the present national system of co-operative loan service did not meet all the day-to-day requirements of the industrial or commercial library, and while the National Lending Library for Science and Technology might solve many problems, it appeared likely to be many years before its service could be put to the test. All the investigations made had illustrated the need for local information services and liaison between all the parties concerned. Local schemes of co-operation, however, required a few paid servants to implement policy if co-operation was to be effective. Mr. Wright thought that it was a pity that, in spite of its vital interest in the free flow of information, the Department of Scientific and Industrial Research should be unable to offer financial support to areas where librarians were anxious to co-operate but unable to provide the necessary staff. Such support should be conditional on industry and local authoritios continuing to provide an adequate flow of scientific and technical literature. Finally, he referred to the opportunity for a co-operative research organization capable of producing more efficient microtext readers, information retrieval units, and simple photocopying apparatus.

In the course of a paper reviewing the publications and catalogue service of H.M. Stationery Office, Mr. P. McGrath, director of publications, said that the Stationery Office had again been reviewing its catalogue practice and had decided to initiate informal discussions with representative librarians with the view of achieving a compromise which might yield a catalogue more suited to modern requirements. Mr. G. A. Carter, borough librarian of Warrington, in a paper reviewing capital expenditure on building, included both public libraries and school libraries and also libraries in industry (but without giving costs) and in universities, where the estimated cost of five new library buildings due for completion next year was $£ 1,925,000$, roughly equivalent to the total expenditure on all new public library buildings in the past twelve years, although in all fourteen university libraries the book stock had increased by only 1.5 million compared with 24 million in public libraries. Mr. Carter also cited figures showing the extreme variation in expenditure on libraries by different 
local authorities, and he, too, insisted that the new National Lending Library for Science and Technology would not dispense with the need for technical libraries in the municipal and county library systems.

In a stimulating paper of some general interest, Dr. J. Trenaman, lisison officer for further education, British Broadcasting Corporation, under the title "Libraries as a Social Force", described a survey of opinion towards broad educational ends, from which he concluded that about 55 per cent of those in the sample were at least receptive to new and even unwelcome ideas, while the remaining 45 per cent were resistant, at least to the extent of avoiding unaccustomed ideas or not being interested. This resistant sector had usually received only an elementary early education, whereas those who were interested in education had had a fairly good early education, about half having been to a secondary school. They were interested in the more serious radio and television programmes and were also members of a library. There was an upper level of 25 per cent of the whole sample who had mostly received a grammar school education, with a keen interest in further learning and who would be the more serious readers in the libraries. Dr. Trenaman believes that the machinery of education as a whole operates selectively, and accordingly the chief responsibility for adult education rests upon the informal agencies, especially the public library service, the Press and the broadcasting authorities because they have an access denied to all other information agencies. $\mathrm{He}$ also emphasizes the profound and durable influence of our early education.

\section{EFFECTS OF PLANT DECOMPOSITION PRODUCTS IN THE SOIL}

\begin{abstract}
$\mathrm{T}$ HE inhibitive effects, on the germination of seeds and on seedling growth, of products from decomposing plant materials in soil have been examined by Z. A. Patrick and L. W. Koch (Canad. $J$. Bot., 36, 621; 1958). Substances capable of inhibiting the respiration, germination and growth of tobacco seedlings were obtained after residues from timothy, corn, rye or tobacco plants had been allowed to decompose under appropriate conditions in the soil. Bio-assay tests, based on manometric methods, made it possible to determine some of the conditions under which the decomposition gave rise to phytotoxic by-products and to obtain rapidly an accurate measure of the degree of their toxicity.

Among the factors affecting the production of the toxic products, the species and stage of maturity of the plant material added, the water content and $p H$ of the soil, and the length of the decomposition period, were the most important. Substances capable of reducing the respiration of tobacco seedlings by 50-90 per cent were consistently obtained when any of the plant residues examined had been decomposing for 15-25 days under conditions of high soil moisture and a $p H$ value of the soil solution below $5 \cdot 5$. Tim. othy yielded substances with the highest toxic activity, followed by corn, then rye, and finally, tobacco. Aqueous extracts of unamended soil or of macerated
\end{abstract}

tissues, prepared either before decomposition or when decomposition was inhibited by autoclaving, were not toxic. The toxic substances, obtained by water extraction, showed an inhibiting effect on respiration of tobacco seedlings after an exposure of less than one hour and also induced darkening and necrosis of root cells. Some extracts affected the cells of the apical meristem most severely while others affected only the cells of the elongation region.

The toxic substances have not yet been identified, but they were relatively non-specific in their action, affecting several test plants in approximately the same manner. Many of them possessed antifungal activity. They were soluble in water, insoluble in petroleum ether, stable in acid, and most active in the $p H$ range $4 \cdot 5-5 \cdot 8$. They were precipitated by alkali and their activity was markedly reduced when they were readjusted to the acid-range. They were also stable to heat and did not lose their activity in storage at $1-3^{\circ} \mathrm{C}$. provided they were covered by a layer of toluene. Because of their rapid production and their marked injurious effects on various plants, the authors consider that these toxins may be important under field conditions as the primary factor in some root rots and in predisposing plants to attack by organisms not normally regarded as being pathogenic.

\section{THE NATIONAL INSTITUTE OF AGRICULTURAL BOTANY}

\begin{abstract}
T HE report for 1957 of the National Institute of Agricultural Botany has recently been published*. The Trials Branch of the Institute has, as usual, carried out an extensive programme of work and the performance of a large number of varieties of the main agricultural and horticultural crops has been assessed. A very special requirement of sugar beet varieties is resistance to bolting, and the results are given of a special series of early-sown sugar beet trials designed to test resistance to premature flowering. The new variety from the Cambridge

- National Institute of Agricultural Botany. Thirty-eighth Repor and Accounts, 1957. Pp. 56. (Cambridge: National Institute of Agricultural Botany, 1958.)
\end{abstract}

Plant Breeding Institute, known as Cambro, gave less than 1 per cent of bolters compared with commercial varieties where the percentage varied from 5 to 20 . The potato trials have included for the first time a number of foreign varieties from the Continent and North America. The work of the Seed Production Branch has continued to expand, and as well as administering the various field approval and seed certification schemes the Branch has intensified its inquiries into problems of seed production.

The report covers the first full season of operation of the national scheme for the comprehensive certification of herbage seeds. In launching a scheme covering 25,000 acres in its first season, the 